\title{
The diagonal city: Crossing the social divisions
}

\author{
Roberta Gironi \\ Departamento de Proyectos Arquitectónicos, Escuela Técnica Superior de Arquitectura, \\ Universitat Politècnica de València. Spain \\ E-mail: roberta.gironi@gmail.com
}

\begin{abstract}
Contemporary cities are affected by transformations that put in discussion the claim of control and stability to which the urban project aspires. All those gradual adjustments are manifested according to the demand, bring toward a less formal and more flexible spatial order, for which the traditional forms of the "static" city become the background of the "kinetic" landscape of informal cities. On the contrary of the formal processes of urban planning, informality process is configured as an organic development model and a flexible dynamic system opened to changes. The informal space is produced according to principles of spontaneity and self-organization. A consideration on the possibility to assume different approaches can be proposed. Those approaches should integrate in the design reasoning all the dynamics usually excluded by the discourse on the urban project, which processes can become catalysts to enrich the methods of planning and design of the urban space. Through the analysis of the case-study Previ Lima and the Living Room at the Border of St. Ysidro, the aim is to delineate in which way the contemporary architecture can absorb and metabolize these processes, triggering a different approach to a different method to intervene in the spaces of relationship among formal and informal. It is believed that the informal urban qualities cannot be eliminated and is impossible to ignore the inhabitants' practices, but rather to work on the intersection between collective and individual actions.
\end{abstract}

Keywords: Informal processes, dynamic transformation, new planning approach, flexible space, self-organization

\section{Introduction}

Addressing the issue of informality is quite complex. Cities are undergoing fast processes of change which are making the boundary between formal and informal weaker and weaker. The origin of the word informal is related, first and foremost, to the acknowledgement of an economic market beyond the formal rules of the official one. It was only in the ' $80 \mathrm{~s}$ that the term started to be used with reference to physical aspects of spatial shape and, therefore, to city planning. The fact that flexibility and change are intrinsic factors of the contemporary society is an issue of paramount importance: it inevitably takes the discussion towards a in-depth analysis of informal processes that become integrated in stabilised realities like planned cities. Indeed cities are containers of different forms of urbanism that coexist or collide in a continuous attempt towards a synthesis, giving them a multi-faceted appearance. According to Rahul Mehrotra, such a continuous tension produces an intertwining of formal city and informal city or, using his words, of "static city" and "kinetic city". The physical manifestation of the static city becomes the background of a dynamic landscape and, therefore, temporal of the kinetic city (Hernandez F., Kellett P., Allen L.K.; 2010).

The intrinsic dynamism of the informal 
city has a typically temporary character which is often related to the use of non-durable materials (plastic, wood waste, scrap of various kinds, etc), that make this dynamism hard to figure out in a bidimensional way. On the contrary, this happens in the static city. On the one hand the concept of the static city is grasped through the representative value of its architectures, on the other hand the concept of the kinetic city is related to a specialization of associative values that it implies, resulting thus connected to a specific occupation modality of the spaces. Informality is thus conceived in a wider acceptation which is related to its development and articulation in time according to a local logic, being tightly connected to occupation of the space it creates, and thus specifically bound to the situation. Conversely, the static city aims at codifying the space in an abstract, generally valid order. The instability and the temporary character of the kinetic city are related to the logic of spatial appropriation by inhabitants. Indeed the frequent demolitions and evictions hat are carried out in such realities by institutional police, force inhabitants to find solutions that have a degree of flexibility and mobility through systems of resources recycling and saving. Yet, this separation between static city and kinetic city doesn't end up being a dichotomy without any points of contact nor interactions. On the contrary the intertwining they generate reveals a rich urban condition which is not connected to a "big urban vision, but to a big regulation".

The interrelation of static city and kinetic city, from different points of view (economic, spatial, organisational, etc.) makes the boundaries between the two terms weak and supports an overall view that is more oriented towards concepts like hybrid and simultaneity aiming at conceiving informality as a "contagious phenomenon that will humanize the city" (Hernandez F., Kellett P., Allen L.K.; 2010).

According to a vision of the two terms that rejects dichotomy in favour for a dialogic concept that integrates the two aspects, we ought to shed light on something that is often neglected or simply not considered in the project: the informal and spontaneous practice which is bound to the use and appropriation of the spaces by inhabitants. The relation that establishes between spatial form and social, economic and cultural processes is complex and, as such, requires an "open" analysis that refuses an approach of dogmatic meaning giving of the terms. Considering the complexity and the size of the phenomenon, greater delimitation and definition of the field are considered necessary in order to identify its manifestations which not always coincide with the mere physical appearance of the city, but which are actually related to the organisation itself, be it social, economic or cultural.

Thus, the relationship between formal and informal is perceived as a socio-spatial continuum and such a continuity is mirrored in the city's organisation and in the process of space appropriation. The large introduction about the expanded boundaries of informality prepared the ground for an analysis of which project characteristics can be catalysts of these fields, emphasizing the necessity to hypothesise a wider operational approach which would be valid in general terms, instead of limiting it to the merely informal reality in the physical sense.

\section{The PREVI-Lima project: encounter between informal city and urban design}

Currently, the city of Lima has almost nine million inhabitants, the $70 \%$ of which lives in informal accommodations. The matter of informality in Perù has already been tackled in the past by the architect John Turner, who writes speaking of the owner of a house in a barriada ${ }^{1}$ : "la ve como el arquitecto mira a su edificio en las etapas delicadas de su nacimiento; no como el desastre que parece en ese momento ni como el caos que ven los no entendidos, sino como una promesa de lo que está por venir" ${ }^{2}$ ( John F C Turner ; 1963).

Turner used to see exactly in the barriadas the solution to the problem of accommodation for the poor and claimed that self-constructed houses near the city centre were the solution to rural immigrants' problems since the position allowed to save time in the journey to work, which did not happen by decentralizing them in the suburban areas. With his expression 
"housing is a verb", he highlighted a separation line between the "helpful shack" and the "oppressive house", stating, in this way, the importance of the houses' use value (McGuirk J., 2015).

The remarkable increase of the population of Lima between 1940 and 1960, which was due to the migration of big masses seeking a job from Andeans regions towards the city, generated, as a result, a further increase in the creation of fabrics called "young towns". They were real barriadas that arose concerns in the Peruvian government. During the first administration of the architect and urbanist Fernando Belaúnde (1963-1968) housing programmes were undertaken in order to find a solution to this phenomenon. The activities aimed at building social housing and accommodations for the middle class. Lastly, an experimental housing project was launched: the PREVI (Proyecto Experimental de Vivienda).

The experiment (1965-1973) is the result of the cooperation among different actors: the Peruvian government, the United Nations Development Programme (UNDP), the United Nations (UN), the Banco de Vivienda de Perù and the British architect Peter Land who was entrusted with the project supervision. The government provided economic capitals, local staff and the lands, the UN and the UNDP contributed with technical assistance, international staff and bearing the costs of the international competition.

The PREVI was divided into 3 experimental projects: the PP1, which was focused on the building of a new district; the PP2 that aimed at recover a degraded fabric through a series of operational plans; lastly the PP3 that involved the project of the services and the arrangement of the lots for the rationalization of selfconstructed houses.

After the earthquake that destroyed most of the city of Lima on the 30th May 1970, the PP3 was divided into two subprogrammes: a self-construction project of the Ministerio de Viviendas on the one hand, and a post-disaster reconstruction project on the other hand (PP4), which was based on earthquake proof systems and the employment of local materials with methods of self-construction.
For the experimental project PP1 an international competition was organized, where the requirement in the announcement was the design of short houses at high density -vivienda de baja altura y alta densidad $(\mathrm{BAAD})^{3}$-. World-class Architects were called to participate, in total 13 international teams and 13 Peruvian ones under the direction of Peter Land.

The land of about 40 hectares $8 \mathrm{Km}$ north of the centre of Lima would see accommodations for 1500 families on lots of 80-150 square meters rising up with houses of 60-120 square meters with one or two floors, but able to bear the addition of a possible third one.

The PREVI was conceived as a formal district that could develop informally, a platform for its transformation, where the houses were nothing more than the principle itself and not the final objective. It was a real urbanistic collage in which each architect analyzed the behaviors of the future users and transformed them into living spaces. The novelty, indeed, was Peter Land's choice to build the kind of houses with a patio that belonged to the Peruvian tradition instead of building the tower blocks typical of the social construction of the " 60 s. The limited height would allow the following development: what was recognized and absorbed of informality was the growth capacity, in line with the fundamental principle of the barriadas according to which a house is a process and not an immutable object (García-Huidobro F., Torres Torriti D. and Tugás; 2008).

What makes the success of this experiment so evident is the fact that although the economic conditions of the inhabitants changed, they did not move, they stayed in the district making changes and improvements and transforming a district of social houses in a vital fabric similar to the one of the middle class. The main aim was to develop a generalized method that would be applicable and reproducible, becoming thus part of housing policies of the Peruvian government. The project aspired to build lowcost houses with the related services based on the development of innovative technological solutions by better exploiting resources and by cutting building costs through innovation of the construction methods. It is precisely in the building rationalization and in the prevision 
of the future continuous growth in the initial phase that is the importance of the experiment: the project is considered a transitional stage where to channel the fulfillment of inhabitants' needs and not an end point.

The project design implies associative and growth forms that would stimulate the formation of the neighborhood also through the compactness of the conglomerates, spaced out by small squares accessible on foot from narrow streets. Moreover, the low- cost prefabrication system and the one of dry-stone assembly would implement the local industrial production. Although in some cases choices that belong to the prefabrication on a large scale from Europe have been preferred (Polish and German solutions), in general the PREVI had a series of proposals where there was a union of industrialized techniques which are popular in Europe with the state of development of the Peruvian local reality of that time. It all lead to a choice that aimed at a more than industrial rationalization of the constructive system itself through compatible elements according to a logic that grasped the local construction modalities, allowing thus a further development by the inhabitants themselves. (E.g. TabiblocSpain, lighten panels - Switzerland, modular concrete blocks - Colombia).

The PREVI provided a planning key that perceives architecture as an open process which is in continuous transformation in order to adapt to its inhabitants' needs. The houses, indeed, were thought for families with two to six children and they also considered wider families of 10 people. The acknowledgement of the extended familiar composition, related to informal economic activity, allowed to structure living spaces based on the multi-family home. Indeed a different composition of the Latin American family has been acknowledged, which is more extended than the European one, bound to a precise and restricted family unit.

There was possibility of growth and development thanks to expansion devices of the project that allowed a dual direction of the expansion: vertically, through static devices (ladders and technical installations that have been prolonged), horizontally, through dynamic elements (patios, gardens and terraces that have been modified and contaminated in order to insert new spaces or uses) (García-Huidobro F., Torres Torriti D. and Tugás; 2008).

The expansions and modifications that inhabitants added changed the district's overall image both in terms of buildings' height, since, from the three floors of expansion they reached four or five floors in some cases, compromising their static stability, and in terms of uses. Indeed commercial activities were introduced in the residential fabric, eliminating thus the distinction between public and private spaces.

\section{The experience of San Ysidro - Living room at the borders}

The border line between The United States and Mexico stretches for more than $3000 \mathrm{Km}$ through four states of the USA (California, Arizona, New Mexico and Texas) and six Mexican states (Lower California, Sonora, Chihuahua, Coahuila, Nuevo León and Tamaulipas). Most of the cities along this border have an intense series of economic, social and cultural relationships with the corresponding cities beyond it, to an extent that they can be considered twin cities, just as it happens with Sand Diego and Tijuana. This reality which is rich in relationships and exchanges leads to the creation of a different kind of city which is related to the concepts of transculturalism and multiculturalism. On the one hand San Diego is the symbol of a kind of town planning based on control and planning from above, according to the logic of separation and exclusion (gated communities), on the other hand, Tijuana is a city that can be considered hybrid, the result of informal layerings and dynamic processes of transformation from below.

Such an emblematic situation of the border territory between The United States and Mexico reveals the difficulties of an area that absorbs different migration and cultural flows and has a double value: on the one hand it unites the city in commercial terms since it allows the productive flow to take place (also guaranteed by the Free Trade Arrangement N.A.F.T.A.), and, on the other hand, it creates a clear separation from the anti-immigration objective. 
The exchanges that take place through the wall that separates the American part from The Mexican one create relationships of interdependence between the two parts which make this division porous and uncertain, by activating cultural exchanges that generate contamination. Speaking about globalization nowadays implies pondering on the idea of boundary and on the spatial meanings that it encloses. According to Pietro Zanini the term boundary refers to a vital space of cultural hybridisation, but also a space of contrasts, a membrane that lets different realities pass through its pores in an interpenetration process that continuously strives to balance (Zanini P.; 1997). The main theorist of the frontier, the architect Teddy Cruz (professor at the University of California, San Diego) can be considered a "cultural activator in critical areas" and he managed to find a common point between the Mexican informal urban dynamics and the gated communities of American suburbs. He conceives the border line that divides the two cities as part of an imaginary line that he defines as "political equator", that is to say a line that stretches along the Equator and that marks the distinction between formal North and informal South and between the developed world and the developing one (Cruz T.; 2008).

San Ysidro is located in the South part of San Diego (the current border line was established in 1848, after the annexation of the area to the United States), a community made up of Latin American immigrant families located on the border with Mexico, to which its develop as a frontier crossing territory is to be attributed.

The San Ysidro experience, developed by the ETC (Estudio Teddy Cruz) in collaboration with the Casa Familiar ONG, starts from an analysis of the ongoing processes in the San Diego territory in the border area with Mexico. In this area, it was noted that informal settlements grew faster than the central areas, according to dynamics that resembled Tijuana's settlements across the border.

According to this logic of informal spatial organization, an intervention was undertaken involving the introduction of heterogeneous elements to the system that could channel planning towards development prospects through a real process of "urban acupuncture".

In addition, Teddy Cruz makes use the concept of the use of multi-dimensional space in informal settlements, according to which a home is a microcosm capable of performing various functions (multifamily home, commercial space, cult place).

The project Living Rooms at the Border is significant for its proposal to combine private life and common activities through a combination of functions (multi-family homes, services and infrastructure) inspired by the spontaneous housing aggregation system of the Tijuana urban center.

The housing units are surrounded by a public garden and are built on a concrete structure in which the ground floor is considered a urban plant capable of performing community and collective functions, privileging an open and indefinite character and avoiding a specific definition.

The living area is a place of family conviviality and is often in common, while the church fulfills the function of a multifaceted social center. The main objective of the project was to convert unused lots into a dense and rich housing program integrated with a range of services.

The project uses the bar code logic, cutting the lot into thin strips allocated to different uses and activities (open spaces, closed, opencovered, public and private) maintaining a flexible system ready to accommodate to the changing community's reality.

The functional program is based on two parcels, the first one offers different types of housing (small flats, larger family houses, studios for artists and flexible units for temporary guests) assisted by a service system, while the second lot includes houses for elderly people with built-in nursery schools, according to the concept of intergenerational system (McGuirk J.; 2015).

An important feature of the project lies in the involvement of several actors that have allowed the development of the design chain, allowing communication and collaboration between the various parties involved. The non-profit company Casa Familiar has been fundamental in mediating between institutions and residents both from a social and economic point of view, 
by carrying out bureaucratic procedures until residents have acquired housing units.

The main characteristic of this experience was the creation of a participatory microdevelopment model, a real micro-policy strategy (AHOZ - Affordable Housing Overlay Zone) where housing is seen as a system of economic and cultural interaction, which make the residing community an active component of the whole process.

The fundamental novelty behind the idea of the project lies in the diversified use of the land, Cruz claims in this regard that: "Necesitamos un nuevo concepto de densidad. La densidad se sigue midiendo como un número de cosas - de unidades - por hectárea. ¿Por qué no medirla como el número de intercambios sociales y económicos por hectárea?"4 (McGuirk J.; 2015). In this sense, Teddy Cruz's study has seen in social density, not the housing-density, the key to the success of the initiative.

All stages of the project have been supported by a number of political structures that initiated a development process in which the ONG Casa Familiar could act as a promoter and facilitator between institutions and residents, promoting a subsidy system and administering microcredit to individuals. Redefining the concept of ownership has been the core of the project itself, as residents have become partners of Casa Familiar and therefore co-owners of resources and active part (Cruz T.; 2008).

The innovative character is considering the value of the project as a spatial capital that can generate exchanges and interrelations, enabling socialization and avoiding marginalization of people.

\section{Conclusion}

In the cases discussed it is highlighted that the informal city is not conceived as a design tool as such, but as something capable of stimulating the creation of flexible spaces, hybrid environments that allow the dynamic qualities of the kinetic city to manifest themselves.

In PREVI Lima, thanks to the variety of housing solutions since its first conception, it was possible to adapt the spaces to the needs of the inhabitants, avoiding urban monotony.
The monofunctional nature that characterized the district at the beginning was contaminated by the spontaneous introduction of commercial activities within the fabric, especially evident in homes that, having double access, are more predisposed to accommodating these activities inside them.

The hybridization to which informal cities tend suggests that projects where there is no separation between public and private space and between different functions and activities can be more able to meet the needs of the inhabitants.

The possibility of foreseeing future expansions with a view of total flexibility has seen a recent improvement in the incremental housing of Alejandro Aravena (eg: Quinta Monroy project). Although in this case enlargement is less free and more constrained than in the PREVI: in Aravena's houses the expansion takes place in spaces between the houses, in PREVI Lima it took place in different directions (from inside out, horizontally, and from bottom up, vertically).

The logic of the fragmentation and assembly of the informal city is transposed into the constructive system, preferring small elements to the large-scale prefabricated systems, this has allowed the inhabitants to fit into this constructive system and integrate it.

Ultimately, PREVI is an urban collage of streets and different types of houses whose outcome is an image of a heterogeneous landscape. Thus, this variety combines the life project of the inhabitants with the project of architecture.

The second case analyzed above, the Living Room at the border of Teddy Cruz, refers to the notion of open-ended projects, which consider the concept of living closely to social and educational programs, thus increasing the capital space of the inhabitants.

The adoption of systems that can combine public spaces for mixed use that join the private aspects of family dynamics with public and commercial activities -it all supported by the collaboration of different actors in finding a meeting point between bottom-up planning and public planning, conceives the theory of mixité, for typology as well as characters involved, as a design strategy-. 
In San Ysidro, inhabitants are active contribution as well as final users and the ONG Casa Familiar is a mediator between institutions and communities. The innovative value of the project lies in the rethinking of the concept of living itself, that, from being a material datum of housing density, gives up the place to cultural exchanges, becoming social density.

Such densification of social exchanges is achieved through a combination of uses able to generate a vital community tension. The hybridization of building types and uses at the base of the design idea gave the possibility to attribute a different value to the houses themselves, and urban complexity is achieved through a series of material and immaterial elements.

The project appears as a mediation between formality and informality according to an interdisciplinary approach, whereby design ideas and urban policies are inseparable.

In line with what Alfredo Brillembourg and Hubert Klumpner claim: "the planned city can neither eliminate nor replace the informal qualities and practices of its inhabitants"s. For them, the XIX century had generated the horizontal city, the XX century the vertical city, and thus the XXI century is the century of the diagonal city, which recaptures social divisions (McGuirk J.; 2015).

The project should be a means of knowledge and a useful tool for re-connecting material and social reality, as well as an infrastructure capable of working on various scales (from the territorial dimension to architectural punctual injections).

\section{Notes}

${ }^{1}$ A shantytown section on the outskirts of a large city in Latin America (source: www. dictionary.com)

${ }^{2}$ The inhabitant sees the house as the architect looks at his building during the delicate stages of his birth; not as the disaster that seems at the moment nor as the chaos generated by misunderstanding, but as a promise of what is to come
${ }^{3}$ Low-rise and high-density housing

${ }^{4}$ We need a new concept of density. Density is still measured as a number of things - of units - per hectare. Why we don't measure it as the number of social and economic exchanges per hectare?

${ }^{5}$ From an interview with Alfredo Brillembourg y Huberto Klumpner, Urban Think Tank founders "La ciudad planificada no puede ni eliminar ni subsumir las cualidades y prácticas informales de sus habitantes. Lo informal persiste; sus fortalezas inherentes resisten y rechazan los esfuerzos por imponer orden. La ciudad totalmente planificada, por tanto, es un mito"

\section{References}

Alexander, E. R., Reed, K. D., \& Murphy, P. (1988). Density measures and their relation to urban form. Milwaukee, Wisconsin (USA): Center for Architecture and Urban Planning Research. Retrieved from http:// dc.uwm.edu/caupr_mono/37

Brillembourg A., Feireiss K., Klumpner H. (2005), Informal City (Prestel Publishing, Munich)

Cruz T. (2008), "De la frontière globale au quartier de frontière: pratiques d'empiètement", Multitudes, 31(1)

Hernandez F., Kellett P., Allen L.K. (2010), Rethinking the informal city: critical perspectives from Latin America (Berghahn books, New York, Oxford).

Jacobs J. (1961), The death and life of great American cities(Random House, New YorkToronto).

García-Huidobro F., Torres Torriti D. and Tugás (2008), ¡El tiempo construye! El Proyecto Experimental de Vivienda (PREVI) de Lima: génesis y desenlace, (Gustavo Gili, Barcelona)

Matos Mar J. (2004), Desborde popular y crisis del Estado. Veinte años después, Fondo editorial del Congreso del Perú, Lima

McFarlane C., Waibel M., (2012), Urban Informalities: Reflections on the Formal and Informal (Ashgate, Farnham)

McGuirk J. (2015), Ciudades radicales. Un 


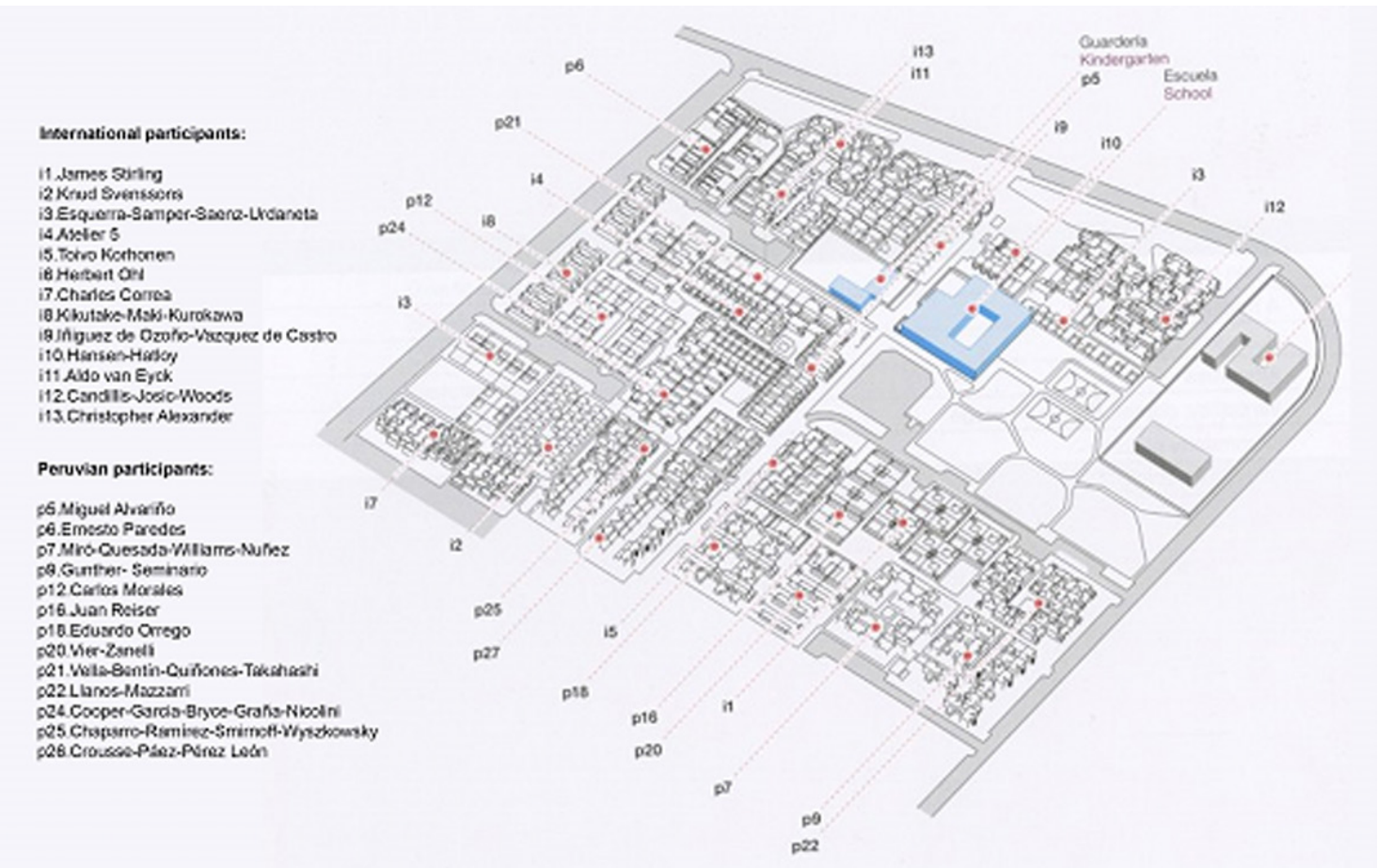

Figure 1. PREVI housing collage (source: García-Huidobro F., Torres Torriti D. and Tugás (2008), ¡El tiempo construye! EI Proyecto Experimental de Vivienda (PREVI) de Lima: génesis y desenlace, (Gustavo Gili, Barcelona)
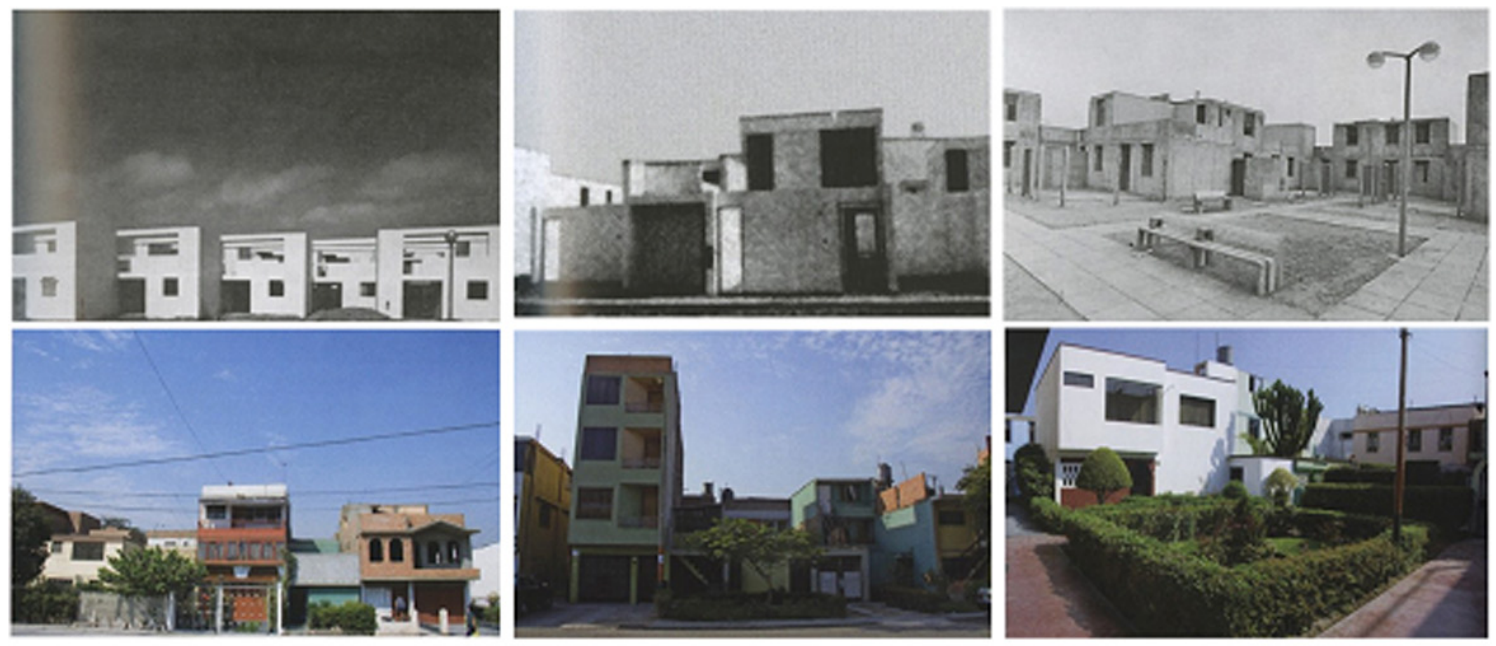

Figure 2. Growth and development of PREVI Lima from 1978 to 2003, from left to right: Miro-Quesada-Williams-Nuñez project, Josic-Candillis-Woods project and Charles Correa project (source: García-Huidobro F., Torres Torriti D. and Tugás (2008), ¡El tiempo construye! El Proyecto Experimental de Vivienda (PREVI) de Lima: génesis y desenlace, (Gustavo Gili, Barcelona) 


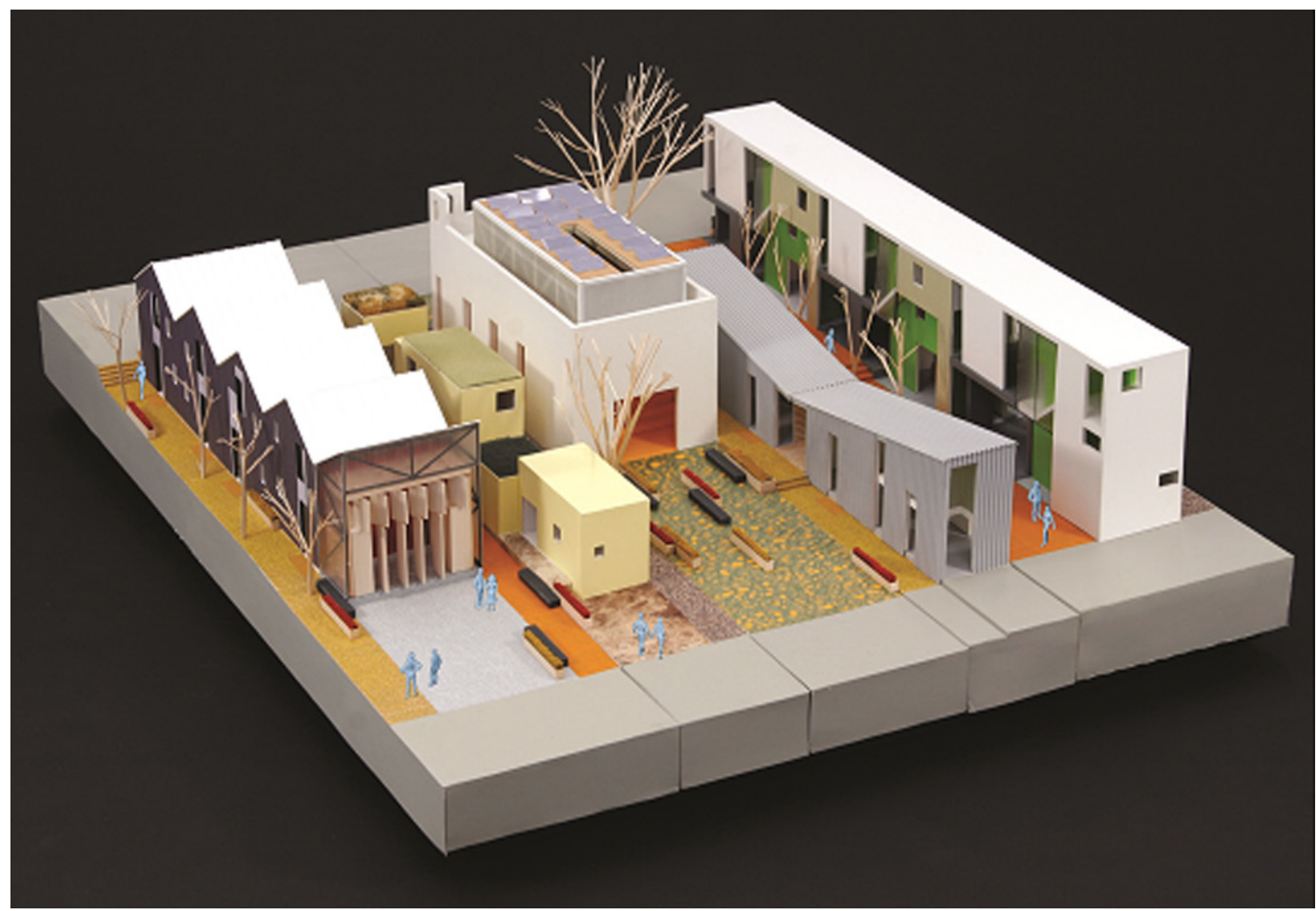

Figure 3.Living room at the border project (source: http://blog.ted.com)

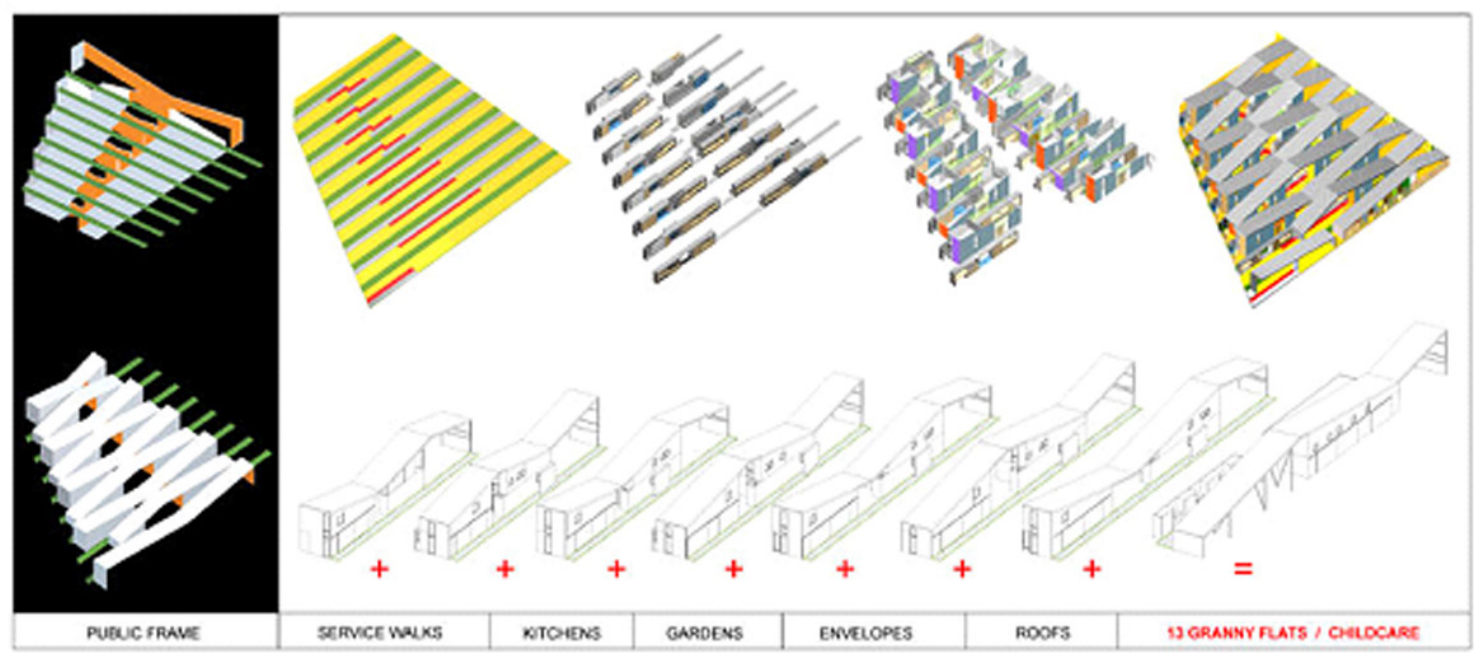

Figure 4. Diagram for Senior Housing with Childcare. (source: www.moma.org from Estudio Teddy Cruz) 


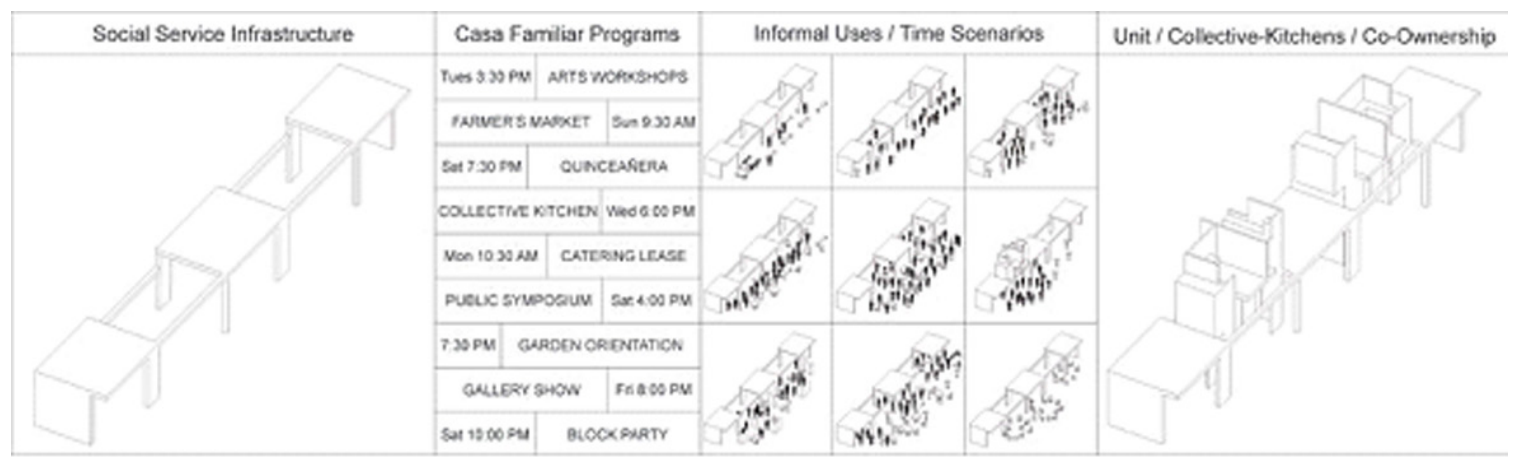

Figure 5. Applications of multiuse frame over time (source: www.moma.org from Estudio Teddy Cruz)

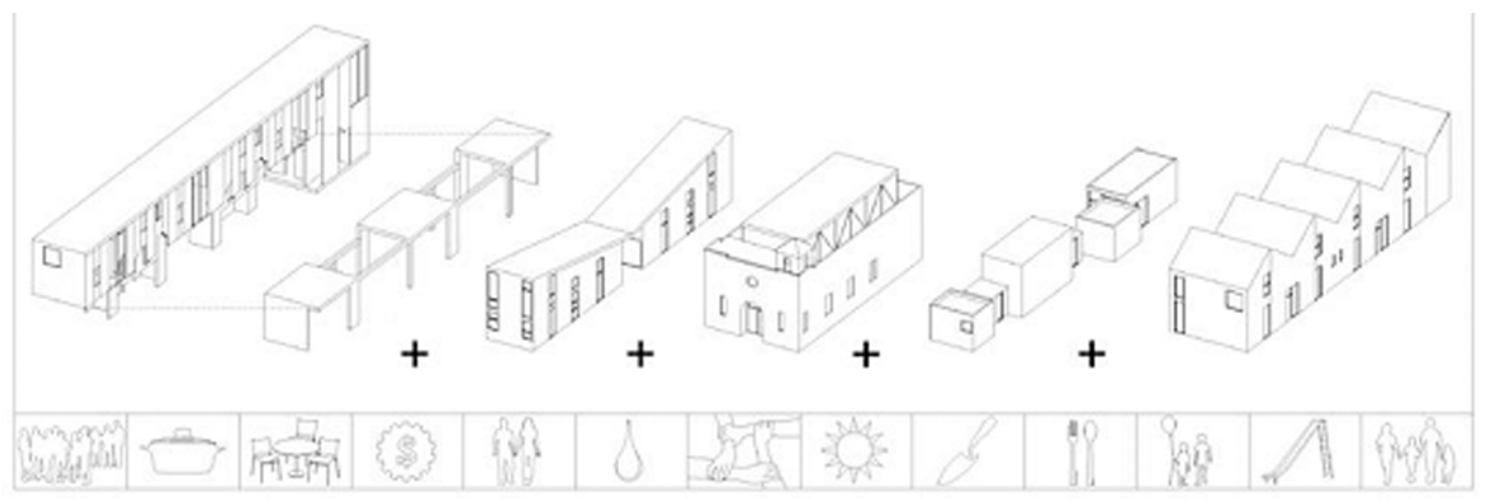

Figure 6. Typologies included in Living Rooms at the Border (source: www.moma.org from Estudio Teddy Cruz)

viaje a la nueva arquitectura latinoamericana, (Turner, Madrid)

Roy A., Alsayyad N., (2004) Urban Informality: Transnational Perspectives from the Middle East, Latin America, and South Asia (Lexington Books, Lanham)

Zanini P. (1997), Significati del confine: i limiti naturali, storici, mentali, (Bruno Mondadori, Milano)

John F C Turner, "Dwelling Resources in South America", Architectural Design 8, August 1963 . 